\title{
Reaching for different ends through tenure track-institutional logics in university career systems
}

\author{
Maria Pietilä ${ }^{1} \cdot$ Romulo Pinheiro ${ }^{2}$
}

Published online: 18 August 2020

(C) The Author(s) 2020

\begin{abstract}
In this study, we used the institutional logics perspective to identify the logics underpinning the tenure track career system, how the logics manifest themselves in recruitment and performance management and how academic leaders and academics negotiate between the logics. The study contributes to research on governance dynamics in academia and to universities' organisational transformation in the context of strategic actorhood. The data comprised interviews with academic leaders (vice-rectors, deans, department heads) and academics in tenure track positions at two Finnish universities. Empirically, the study explores two key areas of human resource management: recruitment and performance management. The findings show that in the area of recruitment, the leaders at the highest hierarchical levels emphasised organisational visions and priorities. On the other hand, academic leaders constantly negotiated on the weight given to the managerial and the professional logics. The managerial logic also stands out in the area of performance management, but in daily life, it is mediated by the professional and the market logics. Theoretically, the findings underscore the complex interplay between different, yet coexisting institutional logics, as well as the agentic role of academic leaders and academics in addressing the tensions that unfold.
\end{abstract}

Keywords Tenure track · Academic careers · Institutional logics $\cdot$ Universities · Organizational transformations $\cdot$ Finland

Maria Pietilä

maria.pietila@helsinki.fi

Romulo Pinheiro

romulo.m.pinheiro@uia.no

1 Faculty of Social Sciences, University of Helsinki, P.O. Box 54, Unioninkatu 37, 00014 Helsinki, Finland

2 Department of Political Science and Management, University of Agder, Universitetsveien 25, Kristiansand, Postboks 422, 4604 Kristiansand, Norway 


\section{Introduction}

Universities face a broad set of expectations and demands. According to the dominant science policy discourse, research should be excellent as reviewed by prominent scholars. Universities should be socially responsible by meeting societal challenges and responding to heterogeneous student needs. At the same time, faced with a competitive funding environment and tight university budgets, universities are expected to be efficient organisations, and they are subject to scrutiny in various forms of monitoring and control (Marginson 2008).

The above examples indicate that universities face a complex social environment with multiple, intermingling and competing institutional orders (cf. Thornton and Ocasio 2008; Kraatz and Block 2008; Greenwood et al. 2011). Modern universities are required to balance between external pressures and expectations (Berg and Pinheiro 2016; Pietilä 2018), which is likely to create difficult trade-offs and tensions in hybrid organisations (Christensen and Lægreid 2011), of which universities are an example. The pressures are also reflected in the expectations about academic work.

Universities in many European countries have been subject to modernisation reforms inspired by new public management (NPM) reforms (e.g. Seeber et al. 2015; Bleiklie 1998). Due to these reforms, universities' governance arrangements have been transformed. Centralised systems have been replaced with more decentralised arrangements and increased organisational autonomy. However, managerial forms of internal governance have not fully replaced traditional, collegial forms of governance in Europe (Seeber et al. 2015). Instead, many universities mix aspects of collegiality and managerialism, indicating that contradictory, institutional logics may operate simultaneously within one organisation.

Universities' employment relationships are also in state of flux. According to Musselin (2013), the interaction between the academic and the university employing that academic has become tighter and more constrained in many countries. Hüther and Krücken (2013, 10-11) argue that especially universities' internal career paths, such as tenure track, attaches the academic closer to the employing university. Academics in a university's internal career path must consider the performance demands set by the organisation, to ensure they are eligible for promotion and tenure, exposing them to new forms of control.

The introduction of tenure track systems is the object of this study. Earlier research on tenure track systems has mainly been conducted in North America and has focused on matters such as the expectations and experiences of academics on the career path (e.g. Acker et al. 2012; Rice and Sorcinelli 2002). The research has uncovered many of the insecurities and tensions academics face when they work under performance evaluation and under pressure to deliver outputs in a limited timeframe.

The focus of this paper is the introduction and institutionalisation of tenure track systems in a national context (Finland), which has followed major policy reforms aimed at modernising the higher education system. This is a topic which has so far received little attention. The establishment of new organisation-specific tenure track systems is an interesting object of study, because it sheds light on the dynamics associated with the change of universities into more coherent, 'manageable' organisations (e.g. Krücken and Meier 2006; Whitley 2008).

Drawing primarily on interview data from two Finnish universities, the aim with the study is to identify, first, the prevalent institutional logics underpinning the tenure track system. Second, the study sheds light on how the multiple logics are woven into the fabric of everyday work of academic leaders and academics, and how they navigate and negotiate between the logics. In doing so, the paper addresses recent calls "to acknowledge the struggles of 
individuals, rather than organizations, operating across multiple logics" (Smets et al. 2015, 935; whilst referring to the work by Goodrick and Reay 2011).

The contribution of the paper is threefold. First, it demonstrates how university actors interpret the changing governance dynamics underpinning academic employment. Second, by examining multiple competing institutional logics in play, it offers insights into the interrelations and tensions between the logics. Third, the paper contributes to the institutional logics and hybridisation literatures by investigating how actors within hybrid organisations deal with pressures emanating from institutional pluralism. The study exemplifies how academic careers at modern universities simultaneously embody elements from various institutional logics, integrating elements which represent both continuity and change (cf. Välimaa 2007).

\section{Institutional logics in academic careers}

In the study, we applied an institutional logics perspective (Thornton and Ocasio 2008; Thornton et al. 2012). The perspective, which functions both as a meta-theory and a method of analysis, offers a link between the macro-oriented, structural perspective on institutions, and the micro-oriented perspective on action and process (Thornton and Ocasio 2008, 100). The macro dimensions are operationalised in the form of societal ('institutional') orders, such as the state or the market. The micro aspects pertain to the manifestation of a specific logic at the local level that is associated with a given order; for example, the purpose of advancing the public good in the state logic (Thornton et al. 2012).

Thornton and Ocasio $(1999,804)$ define institutional logics as 'the socially constructed, historical patterns of material practices, assumptions, values, beliefs, and rules by which individuals produce and reproduce their material subsistence, organize time and space, and provide meaning to their social reality'. Thus, logics that embody interests, values and identities of individuals and organisations are thought to shape individual and organisational practices. Because of the micro orientation, the perspective also enables one to see individuals as proactive agents.

We argue that four institutional logics are especially relevant in the study of academic careers: state logic, managerial logic, professional logic and market logic. The state logic emphasises publicly funded universities as implementers of national political aims. In employment relationships, the state logic represents continuity by providing universities positioned in a certain national context with standardised and uniform conditions for employment and funding. These include national labour regulation and universities' funding models.

The managerial logic emphasises the needs of the university organisation, which are manifested in organisational research and teaching strategies with implications on human resource policies. It emphasises academics as employees of a specific university and the need for employees to comply with management decisions and to follow hierarchical, centralised procedures (Krücken and Meier 2006; Musselin 2007; Whitley 2008). Universities as corporate-type organisations increasingly monitor the productivity and efficiency of academic employees through performance-based management systems (e.g. Kivistö et al. 2017). Performance-based management systems in the public sector aim at rationalising action by collating the delivered outputs of employees into sets of performance indicators and measures, which are presented as objective and transparent information for the broader community (Townley et al. 2003). 
The professional logic rests on the primacy of professionals, such as professors and other senior academics, to control the entry of new candidates into the academic profession and to enact socialisation processes and field-specific performance standards. This logic underscores the professional notions of what constitutes good academic performance, and hence, who should be recruited and promoted to academic positions. It rests on academics' primary membership of the international scholarly community rather than to a specific local organisation.

The market logic emphasises career decisions resulting from free competition. For example, candidates successful in gaining prestigious competitive research funds have been shown to be favoured in recruitment decisions (Fumasoli 2015; Klawitter 2015). This logic perceives academics as flexible entrepreneurs who only have loose ties to a particular university.

The four institutional logics are presented in Table 1. We believe that these ideal-type logics, which have been recognised in previous research (e.g. Goodrick and Reay 2011; Thornton et al. 2012), are central in illustrating how the work of academics and academic leaders is shaped in the realm of academic careers. When it comes to the five key dimensions described in the table, the first three (1-3) relate to structural conditions, whereas the two remaining (4-5) ones pertain to the daily practices of academics and academic leaders. Hence, these two dimensions (control and scope of work) are the focus of our empirical analysis insofar as institutional complexity is associated with the introduction of a tenure track system in Finnish higher education.

However, we argue that the coexisting logics are not exclusive but interact with each other, building both contradictory and supportive dynamics (cf. Goodrick and Reay 2011). For example, the market logic perceives career decisions as an outcome of free competition, as a result of the competition for research funding, for example. However, in this case, the market logic does not reflect unregulated competition with no control by the professionals. On the contrary, external research funding systems are entangled with the professional logic because the funding decisions rely heavily on external expert evaluations. Thus, the decisions represent professional ideas about what constitute significant discoveries in a given disciplinary field. Here, the market and the professional logics are intertwined. This type of market logic diminishes the influence of the managerial logic because the significance of external funding means that the recruitment and promotion decisions are largely controlled by actors outside the recruiting university (cf. Whitley 2008). As for the state logic, governance by the state reinforces competition through performance-based funding models, which in many countries, including Finland, emphasise productivity and efficiency (Kivistö et al. 2017). Similarly, Teixeira et al. (2004), 4) point 'to the complex interactions between the introduction of market elements and the strong regulatory power of government'.

For academics and academic leaders, the coexisting logics imply a need to reconcile and negotiate between different expectations. In their everyday work, individuals negotiate and compromise between the logics (Smets et al. 2015), taking proactive steps to cope with institutional complexity (Greenwood et al. 2011). To enable this, hybrid organisations such as universities may make room for flexibility, allowing organisational members to combine new structural arrangements with local, institutionalised practices (Smith and Besharov 2019; Lepori and Montauti 2020). In their study, Braun et al. (2015) applied the concept of interdependency management. Academics constantly negotiate about the rule of power within universities, where hierarchical management coincides with academic self-organisation, hence forming a delicate balance between the managerial and the academic rule. 


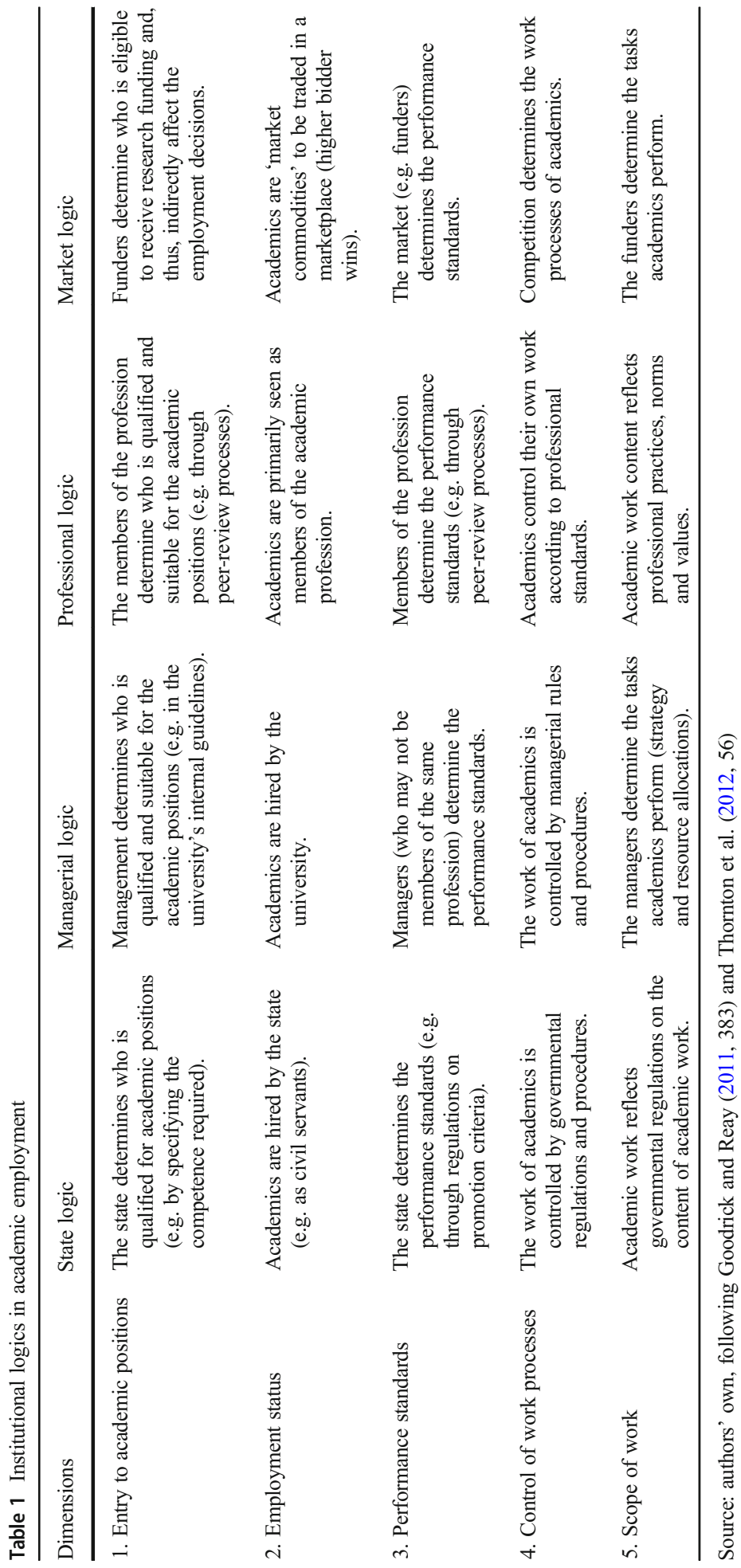


We argue that in Finland, the diminished state logic in academic employment has opened the door for the managerial logic. However, it is an empirical question whether and how it is manifested in different social contexts, and how it interacts with other logics.

\section{Data and method}

Finland is a fruitful case for studying changing academic employment relationships because the governance arrangements between the state and universities underwent reform in 2010 (Aarrevaara et al. 2009). As a result, universities gained new legal status, shifting them from public bureaucracies into either corporations or private foundations.

The first part of the data, conducted in 2014, comprised 14 interviews with academic leaders at two large universities in Finland. The second part, conducted in 2015, comprised 21 interviews with academics in tenure track positions working in the same organisations. It should be noted that in the Finnish higher education system, academic management positions are fixed-term and typically rotating, making management accountability questions complex. Academic leaders are chosen either through election or appointment.

The documentary data collected to supplement the interviews included research strategies prepared at several organisational levels, descriptions of organisational decision-making processes and tenure track guidelines at the time of the study. The documentary data and interviews conducted with the human resource (HR) directors and officials provided information about the organisational goals and tenure track procedures.

Both case universities launched the career system in 2010 in a top-down management process. The formal recruitment, promotion and tenure processes at the case universities have been described in another article (Pietilä 2015). The rationale for choosing the two cases was that, in comparison with other Finnish universities, they had already recruited more individuals into tenure track positions. Both universities are located in the capital area and have a high status as strong research universities in the Finnish higher education system. However, they differ in terms of history, disciplinary fields and management traditions.

University A is a merged university with about 4700 staff and 20,000 students. It consists of units including science, technology, engineering, business, art and design. University B is an established comprehensive university with units ranging from natural sciences, medicine, social sciences and humanities. At the time of the study, it had about 8400 staff and 36,000 students. Overall, the tenure track system was more widely used at University A, whereas at University B, the new career system was being adopted more gradually. At University A, the merger process may have developed an arena for a radical change, resulting in a drastic shift in recruitment and career advancement.

The academic leaders interviewed included two vice-rectors in charge of personnel policies, four deans and eight current or former department heads. The department heads were selected from similar departments to include variety related to academic careers in different fields (cf. Musselin 2007, 2013). The departments encompassed natural sciences/technology and behavioural sciences/business studies. The exact units and fields have not been specified to protect the anonymity of the individuals who participated in the study.

The assistant and associate professors were selected from individually oriented and groupbased (infrastructure-intensive) fields and basic and application-oriented fields (cf. Becher and Trowler 2001). This was to ensure inclusion of those who worked mostly individually and those who were tightly embedded within research groups, with implications on the nature of 
work, such as publishing and funding. The interviewees represented individuals from different career phases, nationalities and genders.

The interviews with leaders covered themes such as the broader context and the goals of the career system, organisational processes and guidelines and how the career system was put into practice. The interviews with academics concerned themes such as the academics' work history and career aspirations, relationships with the university as employer and recruitment, promotion and tenure processes.

The analysis began with a thorough reading of each interview (transcribed verbatim). Occurrences of the interviewees comparing the new employment system with the previous systems were given special emphasis, as this might imply a shift in the logics. The analysis focused on two core human resource practices associated with the introduction of a tenure track system: recruitment and performance management. From the interviews, extracts seen as reflecting the above-mentioned institutional logics were separated from the data. Table 1 was used as an analytical tool to compare the verbal statements in the interviews with the characteristics present in the four ideal logics. In the analysis, the section on recruitment focused on the interview data on academic leaders, because they had broad experience of the recruitment goals and procedures. The section on performance management focused on the interview data on academics in tenure track positions to detect how these academics negotiated between the logics in their work. The selected quotes illustrate how the logics manifest themselves at the case universities and how they are intertwined.

\section{Finland: introducing tenure track as a modern career system}

Finnish universities have been independent financial entities and employers of their own staff since 2010. Although ministerial influence has declined somewhat and regulation has become more focused on outputs instead of inputs, the substantive autonomy of public universities remains limited. Kallio (2014) argues that the detailed governmental budget funding model, coupled with a stagnant level of public funding, severely limits the substantive autonomy of universities. In the Finnish research system, about half of universities' research and development $(R \& D)$ funding comes from governmental budget funding. The other half comes from external $R \& D$ funding. Also, the national funding model, which sets the amount of budget funding for each university, is performance-based. For example, indicators related to research include the number of publications and the amount of competitive R\&D funding granted.

Career progression in Finnish academia has traditionally been based on individuals applying for vacant positions, such as professorships. Most job contracts in Finnish academia have been non-permanent. In 2018, most academics (c. 54\%) with doctoral degrees at universities worked on fixed-term contracts (Association of Finnish Independent Education Employers 2019, 6). Academics have lacked in-rank promotion opportunities and have suffered from insecurity because of the absence of long-term employment and promotion options within one organisation (Siekkinen et al. 2015). Overall, universities as employers and academics as employees form a complex commitment relationship. Despite the urge to focus on one's work in the long term, junior-level academics in particular experience the precarious work settings as a push factor from academia (Siekkinen et al. 2017). In addition, evaluations have observed the low proportion of international academic staff and low mobility as problems in Finnish academia. 
Against this background, universities in Finland introduced tenure track systems in the 2010s. As a university-driven reform, it has been argued that the career system promotes internationalisation and transparency with promises to offer career predictability and promotion opportunities for productive junior- and middle-career academics (Pietilä 2015). Although most academic recruitment and positions still fall outside the tenure track, its significance relates to the universities' ambition to broaden its use in professorial recruitment (Academy of Finland 2014, 9).

In Finland, tenure track is composed of explicit career steps. Despite variations across organisations, the career steps are usually described as fixed-term 'assistant professorship' as the entry-level, fixed-term or tenured 'associate professorship' as the mid-level and tenured 'full professorship' as the highest career level. The difference between the tenure track and traditional academic career progression in Finland is the opportunity to promote or give tenure to an academic (without having the position publicly vacant) based on performance criteria and supported with administrative processes and guidelines. The exact organisational career structures, procedures and guidelines differ between organisations.

\section{Logics in introducing tenure track}

\section{Recruitment}

Recruitment refers to 'the organizations' collective efforts to identify, attract and influence the job choice of competent applicants' (Ployhart 2006, 869). Under the new legislative framework, Finnish universities possess considerable leeway to decide on their recruitment policies, diminishing the significance of the state logic. While the state continues to regulate the tasks and selection procedures of permanent professors to some extent, each university may specify the procedures. The universities' employer status and the significance of organisation-specific HR policies indicate the increased managerial logic in recruitment. At both universities and consistently in all the units, the interviewees considered tenure track recruitment, including the definition of the positions and the appointment decisions, to be part of the research and teaching strategies.

Of course, the opening of these professorships and processes is a management's tool to steer the university. And departments have received different numbers of new professorships, $[\ldots]$ the decisions are based on management's ideas of the strategic aims and the possibilities for success. (Senior leader, natural sciences/technology)

These are the most important things, the most important decisions we make as university: who works here as a professor. Although it takes a lot of energy and there's quite a lot of people involved, it's worth the effort to do the work properly. (Senior leader, behavioural sciences/business studies)

To support the organisational visions, recruitment procedures at both universities followed centralised guidelines with several actors at various organisational levels having responsibilities in the process. These included the rector, deans, university-level and faculty-level tenure track committees, recruitment committees and external evaluators.

Vice-rectors and deans at both universities highlighted the university organisations' overall vision in recruitment. For department heads, the involvement of centralised tenure track committees in recruitment, involving members from various disciplinary 
backgrounds, caused tensions because this represented organisational priorities at the expense of discipline-specific, local knowledge of professional achievement. This was particularly salient at the newer University A with more centralised internal governance. This highlights how the governance arrangements affect how universities respond to institutional complexity and what tensions are likely to emerge (cf. Greenwood et al. 2011). In interpreting the establishment of the career system and responding to it, department heads perceived themselves primarily as representatives of disciplinary fields and their local units, and they tried to bring the disciplinary specificities and their own units' strategic perspectives forward.

[...] And the fact that they [the committees] easily overrule [external] evaluations, which is really odd I think, because the experts are often the best in the world in the field. Somehow the committees should find a common perspective about what the significance of evaluations is. (Department head, behavioural sciences/business studies)

I think it [recruitment] has been formalised [too much], it has made it too rigid from our perspective. And it is too rigid, and it should be changed. You can maybe approve it [the centralised procedures] at the beginning, but not in a long term. I think departments should be allowed to take care of these things. We do much more challenging tasks than the recruitment of assistant professors. (Department head, natural sciences/technology)

Despite the centralised procedures, there was space for local variations, at both the comprehensive University B and at the more collectively oriented faculties at University A. This indicates the flexibility available in practice for professionals to negotiate on the priorities and to balance between the competing interests in individual recruitment decisions (cf. Smith and Besharov 2019; Lepori and Montauti 2020). To enable this, some departments held recurring internal meetings, mitigating the organisational focus with conscious efforts to include the local collective visions in the process.

[...] We have a monthly professors' meeting, at which we handle all the important issues and especially strategic issues. All the professors have a chance to participate there. When we have received a new position [from central management], a slot as it is called here, our professor collective aims to define in what field, what kind of a person we start searching for. And I've wanted to keep the whole process as transparent as possible. [...] As a start, the department head proposes a committee which starts the process; we do the selection of the committee collectively. We agree collectively who will start proceedings. This is the way I have wanted to run the process. When the applications arrive - we know who applied - the committee keeps all the professors aware. [...] When the committee draws up short lists, again all the professors can give their opinion. (Department head, natural sciences/technology)

Consequently, the logics had a different emphasis in different local contexts, emphasising the university as a hybrid organisation. For example, recruitment to assistant professor positions usually involved external expert evaluations. In practice, in different fields and units, the evaluations were weighted differently in the final recruitment decisions. Interviewees, especially at University A, highlighted that not only the strategic visions of the units but also the more diverse recruitment processes when compared to the past have diminished the weight of peer evaluations. In the behavioural sciences/business studies, the case-by-case consideration and weight given to journal rankings was even seen to partly override the significance of peer judgement. 
[the recruitment process] has clearly changed compared to what it used to be in universities, when external reviews were extremely important. They are still important, but their role, if I may say this, has relatively diminished. (Senior leader, behavioural sciences/business studies)

In contrast, respondents in the natural sciences/technology at both universities heavily stressed external evaluations in recruitment, typically seen as 'unambiguous'. This highlights the significance of peers and the continued prevalence of the professional logic in decisionmaking.

$[\ldots]$ if the external evaluations are divided, meaning there is no top applicant, this group [the internal recruitment committee] has full power. If the experts are very unanimous and strong in their opinions, someone is clearly the best, the hands of the group are tied.

Because you can't act against that. (Department head, natural sciences/technology)

Despite the increased role of the managerial logic, recruitment processes continued to rely indirectly on the professional logic, not least because the recruitment criteria strongly emphasised academic achievements such as publishing and international networks. This positioned the candidates closely within their scholarly community rather than the local university.

Reflecting the significance of the market logic in academic recruitment, the candidates' success in the competition for research funding was interpreted as being a proxy for their ability to operate in the research market. Most interviewees especially in the natural sciences/ technology interpreted the acquisition of academically prestigious funding as relevant in the recruitment decisions.

[...] in science it's quite clear that competitive research funding [is appreciated], such as from the Academy of Finland, European Research Council and so on. Its weight is remarkable [in recruitment]. (Senior leader in the natural sciences/technology)

[...] in the phase of short lists, it stands out clearly [external research funding grants]. It doesn't rule out anybody, but it's a plus. (Department head, behavioural sciences/ business studies)

\section{Performance management}

According to a textbook definition, 'performance management is a proactive partnership between employees and management that helps employees perform at their best and align their contributions with the goals, values, and initiatives of the organization.' (Cadwell 2000, 7). Promotion and tenure reviews are a core part of the tenure track system, as they affect academics' progress along the path. Performance management systems, which identify the promotion and tenure criteria academics are encouraged to follow, provide strong incentives for specific forms of behaviour. The fulfilment of the performance criteria is related to promotion and tenure decisions via performance evaluations.

As was the case in recruitment, the state logic was found to play a minor role in performance management, because Finnish legislation includes few provisions for promotion and tenure processes. However, the state may have an indirect influence through the performance indicators in the universities' budget funding models. That is, in trying to maximise their budgets, universities are encouraged to stress the indicators underlined by the ministry in 
assessing academic performance, a phenomenon known as 'gaming' (Bevan and Hood 2006). Moreover, even if the career system (on paper) entails the option to discontinue academics' employment contracts when performance criteria have not been met, the traditions of the state administration, supported by the national labour legislation, could impede the use of this newly vested managerial power.

The interview data show that performance criteria in tenure track positions primarily represented management's ideas of the expected contributions during the career path. Thus, the performance systems themselves emphasised the managerial logic. Although some academics felt they had been able to affect their personal performance criteria, examples also point to the unbalanced power relations in academic employment.

Well, let's say it [the document] was brought [to me] as a final draft, which I was then able to grumble about a bit. And I did grumble about some things, but they didn't go through. [...] The department head had his own strong opinion and he stuck to it. (Assistant professor, natural sciences/technology)

However, the performance criteria themselves strongly emphasised peer-reviewed publications in high-quality arenas and academically oriented research funding, which shows the ultimate dependence on professionals in performance management. For academics, the formal performance criteria mixed with other expectations from the local work environment (students, colleagues), the academic community and stakeholders constituted an array of competing logics with which the academics needed to balance their daily work. Not surprisingly, many academics reported that the formal tenure track criteria guided their scope of work, sometimes at the expense of tasks which were neither recognised nor easily measured, such as community work (cf. Townley et al. 2003). This was especially the case for junior-level academics with fewer scholarly achievements. These interpreted the work in tenure track positions to be different from their earlier positions, referring to the closer control and explicit output measurement in the career system by the university as local employer.

I have this piece of paper that says what I'm expected [to do] (laughs). And I think it's really great. [...] In addition to having a planned promotion route and indicators [...] which I think is really important, in my previous positions I've never been so aware of what I'm expected to do: what contributions and also how many. [...] And this is certainly really useful for anybody doing any kind of work that it's clear what you should do and how much. (Assistant professor, natural sciences/technology)

Mainly what I've experienced is the research side, which is easy to verify: they look at what publications come out. They also acknowledge especially here after three years, if you have papers in review processes. For example, on the second round, it's already acknowledged. But in tenure decisions, they only look at publications. It doesn't help how many papers you have in a process in good journals. (Assistant professor, behavioural sciences/business studies)

As for the scope of academic work - i.e. the daily tasks academics perform - at both case universities, it was determined mainly by professional values and interests, with high academic freedom within the position. This was also encouraged by the university employers with their calls for tenure track academics to build their own strategy in research. This shows that despite the organisations' strategic action in recruitment and research policies, academics continued to possess considerable leeway and self-regulation in their daily work (cf. Braun et al. 2015). 
I think my tenure track position is quite independent so I basically don't communicate much with even department members. There's just the development discussion you have at the department, but nothing more. But if there are some questions of course I can ask but in general, you just do your job, you do your research and teaching and you try to do your best to publish your research in good journals and to get good feedback in teaching. (Assistant professor, behavioural sciences/business studies)

However, some academics mentioned cases when having to comply with the needs of the university as an organisation was partly at loggerheads with their personal endeavours, described in terms of professional ambitions, or not adequately rewarded. In cases of conflict, following professional norms and passions was usually seen as more appealing than following the university's performance criteria.

Sometimes even part of the [university] strategy, if I should follow that, is counterproductive for my career, I think. -How? -Because the strategy is a bit misaligned with some incentives. So, the strategy says something, but it's not really incentivised, it's very risky. And [University A $\}$ is trying to become an internationally recognised leading university and so on. So, some of those objectives, they're very risky for assistant professors. Like doing multidisciplinary research and so on. (Assistant professor, natural sciences/technology)

[...] my own academic community is somewhere else, not here. After all, for me this is just walls and a place to work, where I can usually be reached. In my deepest thoughts I don't feel a big long-term obligation to build this whole system. (Assistant professor, behavioural sciences/business studies)

Whereas many academics saw comparison of research performance and competition within the academic community as intrinsic elements of academic work, the salience of journal rankings in evaluating performance stood out in the interviews. The rankings referred to include the Finnish Publication Forum and international journal ranking lists. While the respondents in the natural sciences/technology seemed to be more used to being exposed to measurements of research productivity and impact, this contrasted with accounts from many respondents in the behavioural sciences/business who were only recently exposed to the application of performance metrics. The use of journal rankings in the evaluation of research represents a managerial ideal of simplicity and clarity. For some academics, this type of research evaluation was interpreted as mechanistic and insensitive to field-specific nuances.

Of course, if we think about [the field I am working on], it's so broad, people do such different kinds of [field X], there's no... Even the idea that we would have some common journal, where you could publish, which is just 'the best', is just absurd. But there [in my faculty], people just try to conduct certain kinds of research, which is published in those [ranked journals] more and more because of these pressures. (Assistant professor, behavioural sciences/business studies)

[...] everything in my discipline has a really low ranking in the Publication Forum, so if I actually want to publish in my discipline which I have to do because the tenure track is [field X], then I could not hit these publication marks because the publications in my discipline are wrong in the Publication Forum. But the moment they're going to be corrected is after this [performance] evaluation. So, it's also like do I want to go against the topic of my tenure track position or against the requirements. (Assistant professor, behavioural sciences/business studies) 
At the time of the interviews, University A had granted start-up funding for all the interviewed assistant and associate professors, whereas at University B, the faculties had varying practices. This positioned the individuals especially in group-oriented fields at different starting points.

I haven't received any start-up funding. No no. The start-up packages, I checked from the university's guidelines, are reserved for full professors coming from abroad. I haven't received any automatic funding. (Assistant professor, natural sciences/technology)

[...] it [the start-up package] was enough money to hire say one post doc and one $\mathrm{PhD}$ student for 3 years [about $€ 100000$ per year]. So then, okay, I also got some more from the department and more funding through this doctoral network and so on. So, I think it was enough to give some momentum. (Associate professor, natural sciences/technology)

Overall, the findings indicate the increased global competition for academics and the individualisation of employment relations, which led universities and units to replace statecentred standardised practices with more individual-specific terms of work, including start-up packages and other remuneration. This emphasises the increased salience of the managerial logic as it perceives academics as the employees of the university subject both to managerial control and support structures.

However, reliance on external funders to be able to conduct one's research work especially in the natural sciences/technology led to tensions between the managerial logic (in which the academic is perceived as an employee of the university) and the market logic (in which the academic is perceived as an independent entrepreneur). Even in tenure track positions, in line with the market logic, academics continued to perceive themselves as responsible for their own career progress and research success. The situation in which the university did not comprise a self-sufficient organisation with own resources for research created a moral dilemma of commitment for academics, when they nevertheless had the duty to follow the managerial performance criteria.

There's been a transition here $[\ldots]$ when I look back at my career $[\ldots]$ is that researchers or at least professors are required to show perhaps even greater commitment to the university. But the university commits less and less to help the researchers. For example, the funding of the research group - we get hardly anything from the university. In addition, we have to pay for the use of the infrastructure owned by the university. We don't directly have to pay for the offices that we use, but it feels it's not far either in this system. In a way we do have to pay, because a portion of the money that comes in is taken away to pay the rent. (Associate professor, natural sciences/technology)

Despite the portrayed hierarchical lines of authority, cases in which academics had no performance criteria or the criteria had been unexpectedly revised during the contract showed the incomplete functioning of the managerial logic in the universities. This led academics to follow discipline-specific standards of work, which offered a more stable reference system.

$[\ldots]$ because this is somehow such a changing and hectic world, it is hard to see what the situation will be in years to come [when it is time for the performance review]. That's why I think one shouldn't maybe try to fit the frames set by one employer too much. Because it then starts to limit oneself. When I do something that I think is for the good and interesting, it somehow represents who I really am. And then I know it certainly fits somewhere. If it's not [the name of the university], it is only their [the university's] loss. (Assistant professor, behavioural sciences/business studies) 


\section{Discussion and conclusion}

The empirical findings indicate that the introduction of the tenure track system at Finnish universities has been guided by several institutional logics. The analysis of the interview transcripts of academic leaders and academics showed the influence and intermingling of multiple logics.

Finnish universities acquired a new status as independent private employers in 2010. The universities increasingly position themselves as competitive actors, emphasising their particular strategies and goals as organisations. However, instead of embracing a fully self-sufficient role, the universities act as mediators between the state, the academic profession, the market and their respective dominant logics. This underscores the emergence of the modern university as a hybrid organisation (Christensen and Lægreid 2001) confronting ongoing complexity (Greenwood et al. 2011). Key agents, such as formal leaders with their varying disciplinary backgrounds, positions in the university hierarchy, interests and social interactions play an important role in sustaining a balance to prevent one set of logics from dominating. In addition to leaders, the institutional logics perspective acknowledges individual academics with differing disciplinary backgrounds, career ambitions and personal situations as proactive agents. With their daily practices, they take an active part in shaping the implications that top-down changes have.

In the study, the growing significance of the managerial logic stands out, as highlighted in recent comparative studies investigating the effects of reforms in Nordic higher education (Pinheiro et al. 2019). This can be seen in the emphasis of the organisational priorities in recruitment and performance management. In tenure track positions, academics become 'managed professionals' (Rhoades 1998), who need to respond to managerial ideas about how a successful academic should prioritise their work. Still, even within the employment framework characterised by promotion and tenure reviews, in their work, academics retain considerable room for manoeuvre. This is in line with Braun et al.'s (2015) notion of 'interdependency management' and underlines that the increased managerial logic does not necessarily dismantle the influence of the professional logic (Greenwood et al. 2011). Thus, the study highlights the endurance of and co-existence between competing logics, instead of one dominant logic 'winning' over the others (Greenwood et al. 2011; Kraatz and Block 2008). In turn, this lends support to the claim that in the organisational field of higher education, logic co-existence often leads to increasing structural and cultural hybridisation (Berg and Pinheiro 2016).

The significance of the state logic, through formal regulations, was found to be limited. The state logic operates mainly indirectly through the national performance-based funding model and through maintaining the traditions of the state administration. These findings are aligned with earlier studies indicating the evolving role of the state in the governance of the higher education sector in the context of NPM-inspired reforms (e.g. Neave 1998; Gornitzka and Maassen 2000).

Instead of observing the dominance of one logic over the others, the study underscores the interplay between the logics. Multiple logics interact in hybrid organisations by building complex contradictory and supportive dynamics (cf. Goodrick and Reay 2011; Smith and Besharov 2017; Greenwood et al. 2011). Firstly, the co-existence of the state, the professional and the market logics diminishes the significance of the managerial logic in higher education. Academics' dependency on external funding and established peer networks hinders the universities' ability to act as self-sufficient organisations, a classic argument linked to the resource dependency view on organisational behaviour (Pfeffer and Salancik 2003). This is especially the case in infrastructure-intensive fields with traditions of undertaking research in 
large groups. In the absence of having substantial resources for research of their own, universities' attempts to influence academic behaviour are therefore limited, despite the prevalence of strategic action.

Secondly, the reliance on the members of the academic profession in recruitment and performance management limits organisational discretion in controlling career progression. From an identity/cultural perspective (Douglas 1986), collaboration patterns and joint research interests that transcend organisational boundaries posit the membership in one's global scholarly community as more relevant for academics than one's local university. In this respect, our findings are aligned with earlier evidence pointing to the limits associated with the immediate local environment (university) within the context of the academic profession (Teichler et al. 2013). On the other hand, it may also be concluded that universities' career systems make creative use of the professional logic by incorporating professional standards into the system. Finally, the tradition of rotating academic leadership positions at Finnish universities is likely to further blur the boundaries between the managerial and professional logics.

Despite the existence of formal procedures, in their everyday work, academics and academic leaders continuously negotiated between the existing logics in social interaction. For example, leaders at different hierarchical levels had differing views on what weight should be given to external peer evaluations in recruitment. To find a balance between the managerial and the professional logic in particular, leaders resort to compromising tactics centred on blending the aspects associated with different logics. Despite the existence of new formal (managerialistic) procedures and processes, in a hybrid organisation, flexibility may operate as compromising practice, by ensuring that professionals in specific local conditions retain sufficient leeway to adapt to centralised procedures and processes.

Future studies with a focus on the transformation of universities into complete organisations could pay attention to the interplay between local, national and global dimensions underpinning dynamics within the higher education field. Empirical studies could identify the different logics national higher education systems are influenced by and how these are institutionalised (adopted and adapted) at different organisational and disciplinary contexts. As the study pointed to the imbalance between different actors in negotiating the conditions of work, future studies should focus more closely on the issues of power relations in hybrid organisations, such as universities. For example, studying the social dynamics and interaction patterns behind the reform could unveil some of the power relations between different actor constellations when enacting reforms (cf. Välimaa 2007; Kauko 2011).

Acknowledgements We wish to thank the three anonymous reviewers for their constructive comments.

Funding information Open access funding provided by University of Helsinki including Helsinki University Central Hospital. This work was supported by the Finnish Work Environment Fund, the Finnish Cultural Foundation, the Ella and Georg Ehrnrooth Foundation, the Oskar Öflund Foundation, and the Emil Aaltonen Foundation.

Open Access This article is licensed under a Creative Commons Attribution 4.0 International License, which permits use, sharing, adaptation, distribution and reproduction in any medium or format, as long as you give appropriate credit to the original author(s) and the source, provide a link to the Creative Commons licence, and indicate if changes were made. The images or other third party material in this article are included in the article's Creative Commons licence, unless indicated otherwise in a credit line to the material. If material is not included in the article's Creative Commons licence and your intended use is not permitted by statutory regulation or exceeds the permitted use, you will need to obtain permission directly from the copyright holder. To view a copy of this licence, visit http://creativecommons.org/licenses/by/4.0/. 


\section{References}

Aarrevaara, T., Dobson, I., \& Elander, C. (2009). Brave new world: higher education reform in Finland. Higher Education Management and Policy, 21(2), 89-106.

Academy of Finland. (2014). State of scientific research in Finland: professorial recruitment. Tables and figures 24.10.2014. www.aka.fi/globalassets/awanhat/documents/tieteentila2014/aka tieteen tila 2014 professorien_rekrytointi_241014.pdf. Accessed on 14 January 2019.

Acker, S., Webber, M., \& Smyth, E. (2012). Tenure troubles and equity matters in Canadian academe. British Journal of Sociology of Education, 33(5), 743-761.

Association of Finnish Independent Education Employers. (2019). Statistics 2018. Universities.

Becher, T., \& Trowler, P. (2001). Academic tribes and territories: intellectual enquiry and the culture of disciplines. Buckingham: Society for Research into Higher Education \& Open University Press.

Berg, L., \& Pinheiro, R. (2016). Handling different institutional logics in the public sector: comparing management in Norwegian universities and hospitals. In R. Pinheiro, F. Ramirez, K. Vrabæk, \& L. Geschwind (Eds.), Towards a comparative institutionalism: forms, dynamics and logics across health care and higher education fields (pp. 145-168). Bingley: Emerald.

Bevan, G., \& Hood, C. (2006). What's measured is what matters: targets and gaming in the English public health care system. Public Administration, 84(3), 517-538.

Bleiklie, I. (1998). Justifying the evaluative state: new public management ideals in higher education. European Journal of Education, 33(3), 299-316.

Braun, D., Benninghoff, M., Ramuz, R., \& Gorga, A. (2015). Interdependency management in universities: a case study. Studies in Higher Education, 40(10), 1829-1843.

Cadwell, C. M. (2000). Performance management. New York: American Management Association.

Christensen, T., \& Lægreid, P. (2001). New public management: the transformation of ideas and practice. Ann Harbor: Ashgate.

Christensen, T., \& Lægreid, P. (2011). Complexity and hybrid public administration-theoretical and empirical challenges. Public Organization Review, 11(4), 407-423.

Douglas, M. (1986). How institutions think. New York: Syracuse University Press.

Fumasoli, T. (2015). Strategic management of academic human resources: a comparative analysis of flagship universities in Norway, Finland, Switzerland, and Austria. In B. Culum, F. Robeiro, \& Y. Politis (Eds.), New voices in higher education research and scholarship (pp. 18-37). Hershey, PA: IGI-Global.

Goodrick, E., \& Reay, T. (2011). Constellations of institutional logics. Changes in the professional work of pharmacists. Work and Occupations, 38(3), 372-416.

Gornitzka, Å., \& Maassen, P. (2000). Hybrid steering approaches with respect to European higher education. Higher Education Policy, 13(3), 267-285.

Greenwood, R., Raynard, M., Kodeih, F., Micelotta, E. R., \& Lounsbury, M. (2011). Institutional complexity and organizational responses. The Academy of Management Annals, 5(1), 317-371.

Hüther, O., \& Krücken, G. (2013). Hierarchy and power: a conceptual analysis with particular reference to new public management reforms in German universities. European Journal of Higher Education, 3(4), 307-323.

Kallio, K.-M. (2014). "Ketä kiinnostaa tuottaa tutkintoja ja julkaisuja liukuhihnaperiaatteella...?” Suoritusmittauksen vaikutukset tulosohjattujen yliopistojen tutkimus- ja opetushenkilökunnan työhön. Publications of the Turku School of Economics. Series A-1:2014. University of Turku.

Kauko, J. (2011). Korkeakoulupolitiikan dynamiikat Suomessa. Helsinki: University of Helsinki.

Kivistö, J., Pekkola, E., \& Lyytinen, A. (2017). The influence of performance-based management on teaching and research performance of Finnish senior academics. Tertiary Education and Management, 23(3), 260275.

Klawitter, M. (2015). Effects of institutional changes on requirements for vacant professorships in Germany: a quantitative content analysis of employment advertisements. Working papers in Higher Education Studies, $2015,2$.

Kraatz, M. S., \& Block, E. S. (2008). Organizational implications of institutional pluralism. In R. Greenwood, C. Oliver, K. Sahlin-Andersson, \& R. Suddaby (Eds.), The sage handbook of organizational institutionalism (pp. 243-275). London: Sage.

Krücken, G., \& Meier, U. (2006). Turning the university into an organizational actor. In G. S. Drori, J. W. Meyer, \& W. Hwang (Eds.), Globalization and organization: World society and organizational change (pp. 241257). Oxford: New York: Oxford University Press.

Lepori, B., \& Montauti, M. (2020). Bringing the organization back in: Flexing structural responses to competing logics in budgeting. Accounting, Organizations and Society, 80.

Marginson, S. (2008). Academic creativity under new public management: foundations for an investigation. Educational Theory, 58(3), 269-287. 
Musselin, C. (2007). Are universities specific organisations? In G. Krücken, A. Kosmützky, \& M. Torka (Eds.), Towards a multiversity? Universities between global trends and national traditions (pp. 63-84). Bielefeld: Transcript.

Musselin, C. (2013). Redefinition of the relationships between academics and their university. Higher Education, $65(1), 25-37$.

Neave, G. (1998). The evaluative state revisited. European Journal of Education, 33(3), 265-284.

Pfeffer, J., \& Salancik, G. R. (2003). The external control of organizations: a resource dependence perspective. Stanford, Ca: Stanford Business Books.

Pietilä, M. (2015). Tenure track career system as a strategic instrument for academic leaders. European Journal of Higher Education, 5(4), 371-387.

Pietilä, M. (2018). Making Finnish universities complete organisations: aims and tensions in establishing tenure track and research profiles. Helsinki: University of Helsinki, Department of Political and Economic Studies.

Pinheiro, R., Geschwind, L., Hansen, H. F., \& Pulkkinen, K. (Eds.). (2019). Reforms, organizational change and performance in higher education: a comparative account from the Nordic countries. Cham: Palgrave.

Ployhart, R. (2006). Staffing in the 21st century: new challenges and strategic opportunities. Journal of Management, 32, 868-897.

Rhoades, G. (1998). Managed professionals: unionized faculty and restructuring academic labor. Albany: State University of New York Press.

Rice, R. E., \& Sorcinelli, M. D. (2002). Can the tenure process be improved? In R. P. Chait (Ed.), The questions of tenure (pp. 101-124). Harvard University Press.

Seeber, M., Lepori, B., Montauti, M., Enders, J., de Boer, H., Weyer, E., et al. (2015). European universities as complete organizations? Understanding identity, hierarchy and rationality in public organizations. Public Management Review, 17(10), 1444-1474.

Siekkinen, T., Pekkola, E., \& Kuoppala, K. (2015). The EU human resource strategy for researchers and the working conditions of Finnish fixed-term researchers. Journal of the European Higher Education Area, 3, $111-142$.

Siekkinen, T., Kuoppala, K., Pekkola, E., \& Välimaa, J. (2017). Reciprocal commitmentin academic careers? : Finnish implications and international trends. European Journal of Higher Education, 7(2), 120-135.

Smets, M., Jarzabkowski, P., Burke, G. T., \& Spee, P. (2015). Reinsurance trading in Lloyd's of London: balancing conflicting-yet-complementary logics in practice. Academy of Management Journal, 58(3), 932970.

Smith, W. K., \& Besharov, M. L. (2019). Bowing before dual gods: how structured flexibility sustains organizational hybridity. Administrative Science Quarterly, 64(1), 1-44.

Teichler, U., Arimoto, A., \& Cummings, W. K. (2013). The changing academic profession: major findings of a comparative survey. Dordrecht: Springer.

Teixeira, P., Jongbloed, B., Dill, D., \& Amaral, A. (Eds.). (2004). Markets in higher education: rhetoric or reality? Dordrecht: Kluwer Academic Publishers.

Thornton, P. H., \& Ocasio, W. (1999). Institutional logics and the historical contingency of power in organizations: Executive succession in the higher education publishing industry, 1958-1990. American Journal of Sociology, 105(3), 801-843.

Thornton, P. H., \& Ocasio, W. (2008). Institutional logics. In R. Greenwood, C. Oliver, K. Sahlin, \& R. Suddaby (Eds.), Handbook of organizational institutionalism (pp. 99-129). CA: Sage.

Thornton, P. H., Ocasio, W., \& Lounsbury, M. (2012). The institutional logics perspective: a new approach to culture, structure, and process. Oxford: Oxford University Press.

Townley, B., Cooper, D. J., \& Oakes, L. (2003). Performance measures and the rationalization of organizations. Organization Studies, 24(7), 1045-1071.

Välimaa, J. (2007). On traditions and historical layers in higher education. In J. Enders \& F. van Vught (Eds.), Towards a cartography of higher education policy change. Festschrift in honour of guy Neave (pp. 67-76). CHEPS: Enschede.

Whitley, R. (2008). Universities as strategic actors: limitations and variations. In L. Engwall \& D. Weaire (Eds.), The university in the market (pp. 23-37). London: Portland Press.

Publisher's note Springer Nature remains neutral with regard to jurisdictional claims in published maps and institutional affiliations. 